qualification is still extant in such state, and that no person can be a juror therein unless he is a freeholder.

"This property qualification, in my opinion, is not attached merely as a guard to prevent the juror from being bribed, but for this better reason, that the juror owning property in the vicinage will have a deeper and better interest in 'the life, liberty and property' of his fellow citizens, and in the honest and proper administration of justice, than one who owns nothing. The one has a permanent interest in the community in which he resides, and the other has none."

Chicago, Angust 1880.

Willtam S. BRaceetr.

\title{
CONTRIBUTORY NEGLIGENCE BY PERSONS WITH DEFECTIVE SENSES.
}

THe frequency of cases where suits are brought for damages arising from the negligence of the defendant, brings into unusual prominence the doctrine of contributory negligence. The general doctrine of contributory negligence is well settled, but its application in many cases seems difficult, and the dicta of judges in adjudicating upon cases where this defence is introduced, present contradictions which are apparently irreconcilable. Especially is the extent of this doctrine difficult when we come to that class of persons whose senses are defective either by nature or disease. It is the object of this article to treat especially of this class of cases.

The law of contributory negligence is stated by Wharton thus: "That a person who, by negligence, has exposed himself to injury, cannot recover damages for the injury thus received, is a principle affirmed by the Roman law and is thus stated by Pomponius: Quod quis ex culpa sua damnum sentit, non intelligitur damnum sentire. The same view is taken concretely in the Digest and is repeatedly affirmed in our own jurisprudence:" Wharton on Neg., sect. 300 .

This rule was first distinctly announced by Lord ELLENBorovgH in Butterfield v. Forrester, 11 East 60. That was an action on the case for obstructing a highray. The evidence showed that the 
plaintiff was riding violently when he met with the accident. "A party is not to cast himself upon an obstruction which has been made by the fault of another, and avail himself of it, if he do not himself use common and ordinary care to be in the right. *** One party being in fault will not dispense with another's using ordinary care for himself." No exception can be taken to the rule as stated by the learned and able Chief Justice in this case. The inference that has been drawn from it, however, in some cases, has, we submit, been unwarrantable, and the rule as announced in consequence has been erroneous. In Tuff v. Warman, 5 C. B. N. S. 585 , WighrmaN, J., made these remarks, saying the question for the jury was "whether the damage was occasioned entirely by the negligence or improper conduct, or whether the plaintiff so far contributed to the misfortune by his own want of ordinary care, that but for such negligence or want of ordinary care and caution on his part the misfortune would not have happened." See also Witherley v. Reg. Canal Co., 12 C. B. N. S. 2 ; Ellis v. Railroad, 2 H. \& N. 424; Martin v. Railroad, 16 C. B. 179 ; Bridge v. Railroad, 3 ML \& W. 244 . The natural deduction from this opinion is that the damage must be occasioned entirely by the defendant's fault, and that if any negligence, even the slightest, can be imputed to the plaintiff, he cannot recover. The rule is thus broadly stated in many cases, but the courts of recent years have shown a disposition to recede from this somewhat narrow doctrine.

It would occupy needless time and space for us to trace the history of this modification of the rule. We need only take one case as exemplifying the change of base in this respect. In Radley $\mathrm{v}$. - Railroad Co., L. R., 1 App. Cas. 759, Lord Penzance stated the law thus: "Though the plaintiff has been guilty of negligence, and although that negligence may in fact have contributed to the accident, yet if the defendant could, in the result by the exercise of ordinary care and diligence, have avoided the mischief which happened, the plaintiff's negligence will not excuse him."

Such is the rule as recently declared. It is, however, unsatisfactory, as it seems to do away entirely with the doctrine. It is valuable, however, as showing the tendency of courts to mulct in damages the most culpable party of the two.

That persons of defective understanding and of tender years have special immunities before the law, is now well settled and 
thoroughly understood by the profession. This is a necessary consequence and outgrowth of the rule, that a plaintiff is not entitled to recover, unless he used ordinary care and diligence at the time of receiving the injury. The ordinary care exacted, is that care "which might reasonably be expected from him in his situation." Beers v. Housatonic Railroad Co., 19 Conn. 571. Neither common sense or justice would require the same diligence, foresight and care from a deaf, a blind or an insane person, or from a child of tender years, as from one in the full possession of his faculties.

\section{As to Deaf Persons.}

In Isbell v. N. Y.\& N. H. Railroad Co., 27 Conn. 405, Judge ELLSWORTH made these remarks, which although uttered as obiter dicta are worthy of consideration: "Let us suppose, in this case, that instead of the plaintiff's cattle, the plaintiff himself had been on the railroad track, and that he was too deaf to hear the noise of the train or the ordinary alarm given in such a case. This would certainly have been most culpable and inexcusable conduct on his part, but would it have absolved the defendants from the duty to exercise reasonable care if they saw the plaintiff, or with proper attention might have seen him? Ought they not in that case to check the speed of their train? May they run over him merely because he is on their track? They may well suppose that he is deaf, or blind, or insane, or bewildered, and have no right, as we believe, to continue their headway as if he was not there. If they are bound to ring their bell or sound their whistle, as they certainly are, they may be bound for the same reasons to go further and check their speed a little or to stop entirely."

Accordingly it has been held, that the cases of blind or deaf persons are in the same category, and that a person who, from his deafness or other causes, does not understand calls made upon him to escape danger, is not chargeable with negligence in meeting a danger of which he was unconscious: Telfer v. Railroad Co., 30 N. J. 188; Whalen v. Railroad Co., 60 Mo. 323; Schierhold v. Railroad Co., 40 Cal. 447; Illinois Cent. Railroad v. Buckner, 28 Ill. 299 ; Chic. \& R. I. Railroad v. McKean, 40 Id. 218.

These cases go the whole length in holding, that a deaf person cannot be debarred from a recovery in a suit for damages, by that conduct which would be negligence in a person having perfect faculties of vision or hearing. The same rule of law holds in his 
case as in that of all persons. Infants, persons non compotes men$t i s$, deaf and blind persons must all exercise ordinary care, ordinary care being " that care which might be expected and demanded from any man of ordinary prudence under the circumstances of the case." Their misfortunes enter as an element in the case, to determine whether they have exercised that care which the law exacts.

But what is the degree of caution which the law requires of a deaf person? Is he not bound in the case put above, to take notice that a railroad track is a dangerous place? Is he not supposed to know that it is especially dangerous for him? If he approaches the track for the purpose of crossing, either with a team or witnout, is he not bound to look up and down the track carefully? The law requires that of a person in the full possession of his faculties. Will it not exact it from one whose hearing is permanently impaired? Accordingly, it has been held to be negligence for a deaf person to drive an unmanageable horse across a railroad track, when a train is approaching. It is his duty, it was said, to keep a lookout and avoid the danger; and it is no excuse, that the lorse in crossing turned and ran up the track ahead of the engine or was driven there to avoid it: Ill. Cent. Railroad Co. v. Buckner, 28 IIl. 299.

If the defendants in such a case were guilty of gross negligence, there ought to be no question of their liability. But we submit that they ought not to be mulcted in damages unless in extreme cases. If the driver of a locomotive sees a man on the track in front of him, he has a right to assume that the man is in full possession of his faculties, and that he will get off the track in time to avoid a collision. Such cases are not infrequent, and we are assured by engineers that it is no uncommon thing for persons to continue walking on the track until a few seconds before the engine reaches them. How is an engineer to know that a man walking in front of the train is deaf? He can only judge from appearances, and the conduct of men is such that the fact that a man walks along without seeming to notice the presence of the train, is really of no weight in influencing the engineer's conduct. Besides, the spced required in order to make their connections renders it a very doubtful question whether an engineer should, under such circumstances, slacken the speed or stop the engine.

It should be kept in mind that the plaintiff must prove negligence on the part of the defendants affirmatively. The consider- 
ations offered above are applicable only in an inquiry as to the facts which are sufficient to constitute negligence in a defendant. It has been held, therefore, that an engineer who sees before him on the track a person apparently able to take care of himself, has a right to presume that such person, on due notice, will leave the track, if there be an opportunity to do so; and the engineer will not, in such cases, be chargeable with negligence, if, in consequence of such person's not leaving the track, the train cannot be checked in time to avoid striking him: Jones v. Railroad Co., 67 N. C. 123 ; Railroad Co. v. Spearen, 47 Penn. St. 300 ; Telfer v. Railroad Co., 30 N. J. 188; Railroad Co. v. Graham, 46 Ind. 210; Rex r. Longbottom, 3 Cox C. C. 439 ; Rex v. Walker, 1 C. \& P. 320

\section{As to Persons of Defective Vision.}

Oring to causes which may be readily surmised, the decisions on this topic are necessarily few. Here, also, ordinary care must be exercised, and ordinary care is that care which may reasonably be demanded under the circumstances of each case.

Before any cases arose which concerned persons totally or partially blind, the courts had frequently adjudicated upon cases where accidents had happened in the darkness of the night. In Williams v. Clinton, 28 Conn. 264, it was decided that it is not negligence per se to travel in the darkness of the night unattended, when there can be no lookout. The court held that the fact of negligence on the part of the plaintiff was purely a question of fact for the jury to consider, and sustained the verdict against the defendant town.

That such is the case with reference to persons of perfect vision is palpable. The law requires a person to keep his premises in a safe condition and under all circumstances. Persons riding or walking in the darkness of the night, have a right to presume that the ways are perfectly safe and secure. This rule also applies to the stations of railroad companies or the wharves of steamboat companies: McDonald v. Railroad Co., 26 Iowa 124, the leading case on the subject. See also Cornman v. Railroad Co., $4 \mathrm{H}$. \& N. 781; Martin v. Railroad Co., 16 C. B. 179 ; Longmore v. Raitroad Co., 19 C. B. (N. S.) 183.

In Winn v. Lowell, 1 Allen 178, the plaintiff, a female, sustained an injury in crossing the street. The evidence showed that 
her eyesight was poor and weak, that she usually wore spectacles when walking in the street, but did not wear them at this time, and that she was walking very fast. The defendants, among other requests, asked the court to charge the jury, "If the plaintiff was a person of poor sight, common prudence required of her greater care in walking the streets and avoiding obstructions than is required of persons of good sight." The judge refused to so charge, but instructed the jury that "although the sight of the plaintiff was impaired, vet, unless materially affected, that they should take the state of her eyesight as proved into consideration, upon the question of due care on her part." For error in refusing to charge as requested by the defendants' counsel, the Supreme Court granted a new trial.

Perhaps no exception can be taken to the abstract rule of law as laid down in the opinion of Judge MoRToN, who delivered the opinion of the court. The only question is, whether the charge of the court was not suitably adapted to the facts of the case.

In the first place, it must be observed, that the court in the case above cited, do not intend to lay down the doctrine that a person of defective vision is obliged to exercise extraordinary care. If so, it would be in opposition to the whole current of authorities, and the law exacts extraordinary care of no one (Daley v. Norwich \& Worcester Railroad Co., 26 Conn. 597); they merely say, that the court should have charged as requested by the defendants' counsel (see supra).

Secondly, this case would seem to be in conflict with that class of cases of which Williams v. Clinton, is a specimen. This latter case is strikingly analogous in its circumstances to Winn $\mathrm{v}$. Lowell. There, the plaintiff received an injury while walking in the darkness of the night; in the latter the plaintiff met with the accident in the daytime, through her defective vision. In the former, too, an element existed which was not proved in the latter, the plaintiff having been advised not to go along the elevated highway on which the accident occurred without a guide, and offers of assistance having been refused by her.

In the former case, too, the defendants' counsel requested the court to charge the jury as followis, a request almost identical with that asked in the Massachusetts case, making allowance for the difference in the circumstances, "that if the night was so dark that the plaintiff in passing over the highway in question, could not dis- 
cover the pathway or distinguish other objects along the route she took, on the edge of the highway, or distinguish whether it was an embankment or level ground, and had been warned as to the darkness of the night and the risk of attempting to go without a light or a guide, and persisted in attempting to travel over the highway alone and without a light, the plaintiff could not recover; and that it was the duty of the plaintiff to show that she was in the exercise of ordinary skill and care, and that her own misconduct did not essentially co-operate with the negligence of the defendants in producing the injury complained of."

It will be seen that the request of the defendants' counsel, is very similar to the request asked in Winn v. Lowell; the charge of the judge is also similar. He told the jury, "that they were to inquire whether the plaintiff at the time of the accident, was in the exercise of ordinary care under all the circumstances, and whether she fell from the embankment in consequence of the want of a railing upon it; and, that the question whether there was negligence or want of reasonable care on her part under all the circumstances, was a question of fact for the jury." This charge, as we remarked above, was sustained by the Supreme Court.

The rule of law then announced in the case of Winn v. Lowell, may be accepted as good law (though doubted by the learned authors of the leading treatise on the Law of Negligence; Shear. \& Redf. on Neg., sect. 413), that a person of defective vision is bound to exercise greater care than one in the full possession of his faculties, although it may be reasonably doubted whether under the circumstances of that case, and in view of the other decisions of which Williams v. Clinton is a specimen, the charge of the Massachusetts circuit judge was not sufficiently clear and explicit.

The case of Davenport v. Ruckman, 37 N. Y. 568, will, we apprehend, be regarded as much more satisfactory by the profession, both with respect to the abstract doctrines announced in the masterly opinion of the court, and in the thoroughness with which the case was examined, which contrasts favorably with the meagre report of the Massachusetts case.

In that case the plaintiff sued the defendant for injuries which she sustained by falling into an excavation made in the sidewalk of a public arenue in the city of New York. At the time of the accident the plaintiff was, and previously had been, suffering from amaurosis, or paralysis of the eyes, and the power of vision of both Vor. XXIX.-65 
eyes was impaired. She could not distinguish the features of those she met, but she knew that they were persons walking, and a short time before the injury she had been able, as prover, to distinguish the color of her physician's coat, and was in the daily habit of walking the streets as she had occasion. The court instructed the jury that the circumstance that the plaintiff was partially blind and fell into the opening in the sidewalk in the daytime was of no importance, and that it was not important that a distinction should be made in that instance. And the judge added: "The question is this: whether it was so improper and imprudent for the plaintiff to have gone into the strect unattended in her then condition of eyesight, that it would be negligence on her part to do so, sufficient to prevent her from recovering compensation for an injury she might sustain from the negligence while travelling or passing along the streets." "This," said HuNT, C. J., in giving the opinion of the Court of Appeals, "was the precise question to be determined by the jury, and $I$ think it should have been submitted as a question of fact, and that it was fairly submitted in the above proposition. The streets and sidewalks are for the benefit of all conditions of people, and all have the right in using them to assume that they are in good condition, and to regulate their conduct on that assumption. A person may walk or drive in the darkness of the night, relying on the belief that the corporation has performed its duty, and that the streets or walks are in a safe condition. He walks by a faith justified by law, and if he suffers an injury, the party in fault must respond in damages. So one whose eyesight is dimmed by age, or a near-sighted person, whose range of vision was always defective, or one whose sight has been injured by disease, is each entitled to the same rights, and may act upon the same assumption. Each is, however, bound to know that prudence and care are in turn required of him, and that if he fails in this respect, every injury he may suffer is without redress."

The latter part of this opinion, we think, justifies us in our criticism on the Massachusetts case, by the analogy drawn from the cases of persons receiving injuries in the darkness of the night.

It may be mentioned incidentally that Judge HovEr, a judge of very great ability in the Superior Court of Connecticut, in an important case, refused to follow the authority. of Winn $\mathrm{v}$. Lowell, 
and relied upon this case of Davenport $\mathrm{v}$. Ruckman in rendering judgment for the plaintiff.

Only one case has, to our knowledge, been decided where the plaintiff was totally blind, that of Sleeper $\nabla$. Sandown, $52 \mathrm{~N}$. H. 244. There a man totally blind fell off a bridge through the want of a railing on one side of it. The defendant's counsel requested the judge to charge that, " $i$ is negligence for one totally blind to travel unattended on the public highways, a mile and a half from home, where and in what manner the plaintiff did." The judge, as in the cases above cited, left it for the jury to say whether, under the circumstances, the plaintiff exercised ordinary care. The remarks of Judge LADD, in giving the opinion of the Supreme Court, threw a flood of light on this question. "Blindness of itself is not negligence. Nor can passing upon the highway, with the sight of external things cut off by physical incapacity of vision in the traveller, be negligence in and of itself any more than passing upon the highway when the same things are totally obscured by the darkness of the night." *** "Now if, in the present case, the plaintiff knew or ought to have known that it was dangerous for him to attempt to cross this bridge as he did, his attempt to do so would, beyond all question, be want of due care, and he could not recover for the injury suffered. But he had a right to assume that the bridge was reasonably safe and free from defectthat is, that the legal duty of the town with respect to its condition had been performed, and to act upon that assumption. If, considering its location, the kind and amount of travel usually passing over it, \&c., a rail on one side was necessary to its legal sufficiency, this plaintiff, although blind, had the same right to assume the existence of a rail on each side that any traveller passing either in the day-time or night-time would have; and if an accident happened to him by reason of a want of a rail, his own fault not contributing, no reason can be conceived why he is not as much entitled to recover, as though having the sense of vision, he had attempted to cross by night and the same mishap had befallen him."

To conclude, we can regard these principles as settled by the decided cases :

1. The law requires ordinary care of every one.

2. It never exacts more than ordinary care.

3. Ordinary care is that care which may reasonably be expected of any one in his circumstances. 